\title{
Physicochemical Study of Livestock Farm Oriented Wastewater as a Source of Surface Water Pollution
}

\author{
Jyoti Rekha Mazinder Barua ${ }^{1}$, Poznur Hussain ${ }^{1}$, Razibuddin Ahmed Hazarika ${ }^{1}$, \\ Nur Abdul Kader ${ }^{1 *}$ and Nanda Kumar Roy ${ }^{2}$ \\ ${ }^{1}$ Department of Veterinary Public Health, College of Veterinary Science, Assam Agricultural University, Khanapara, \\ Guwahati, INDIA \\ ${ }^{2}$ Department of Livestock Production \& Management, College of Veterinary Science, Assam Agricultural University, \\ Khanapara, Guwahati, INDIA \\ "Corresponding author: NA Kader; E-mail: nurabdulvets11@gamil.com
}

Received: 11 Feb., 2021

Revised: 09 May, 2021

Accepted: 14 May, 2021

\begin{abstract}
The water from surface source provides sustenance to plants, animals, constituents of the habitat for aquatic animals and to meet importance of agricultural and industrial need. The present study was undertaken to evaluate the physicochemical properties of livestock farm oriented wastewater in and around Khanapara, Guwahati, Assam. Five farms were selected and wastewater samples from these livestock farms were analysed to find out bacteriological quality using standard analytical methods. The wastewater samples were collected on a monthly basis for a period of 7 months. In the present study temperature, total alkalinity, sulphate concentration, total suspended solids, total solids, chloride concentration, calcium concentration, turbidity,electrical conductivity and dissolved oxygen were ranged from $18.21^{\circ} \mathrm{C}$ to $27.87^{\circ} \mathrm{C}, 45.00 \mathrm{mg} / \mathrm{L}$ to $50.25 \mathrm{mg} / \mathrm{L}, 145.99 \mathrm{mg} / \mathrm{L}$ to 165.65 $\mathrm{mg} / \mathrm{L}, 840.24 \mathrm{mg} / \mathrm{L}$ to $875.40 \mathrm{mg} / \mathrm{L}, 1700.96 \mathrm{mg} / \mathrm{L}$ to $1720.81 \mathrm{mg} / \mathrm{L}, 148.19 \mathrm{mg} / \mathrm{L}$ to $164.53 \mathrm{mg} / \mathrm{L}, 155.99 \mathrm{mg} / \mathrm{L}$ to 175.81 $\mathrm{mg} / \mathrm{L}, 936.00 \mathrm{NTU}$ to $943.52 \mathrm{NTU}, 10.20 \mathrm{~ms} / \mathrm{cm}$ to $18.00 \mathrm{~ms} / \mathrm{cm}$ and $14.30 \mathrm{mg} / \mathrm{L}$ to $18.39 \mathrm{mg} / \mathrm{L}$ respectively. Out of 140 samples studied, most of the samples were found to have the different physicochemical parameters within the prescribed limits with exceptions such as Total Dissolved Solids (860.71 mg/l), Nitrate (248.98 mg/l), pH (12.20) and Biochemical Oxygen Demand $(18.25 \mathrm{mg} / \mathrm{l})$. Significant difference between the samples in different months was observed during the study period. Thus, the present study on farm wastewater sources in and around Khanapara indicated that proper wastewater treatment is required in the livestock farms to prevent surface water pollution.
\end{abstract}

\section{HIGHLIGHTS}

(O Physicochemical properties of livestock farm oriented wastewater in and around Khanapara, Guwahati, Assam

(0 Proper wastewater treatment is required in the livestock farms to prevent surface water pollution

Keywords: Wastewater, physicochemical properties, Surface Water Pollution

Water is the elixir of life and abounds on earth, but this vast natural resource has been depleted and turned into scarce commodity with increased usage catering to the needs of ever expanding population. Water is the most essential commodity for existence of life and is one of the most important renewable resources. Life and water may be aptly said to be two faces of the same coin. Wastewater includes any liquid waste from agriculture, domestic means, industries, human excretion, commercial sectors, pharmaceuticals, healthcare units of water which quality has been deteriorated under anthropogenic influence (Buelow et al., 2017). The sewage water is not treated before being discharged into waterways, which causes

How to cite this article: Barua, J.R.M., Hussain, P., Hazarika, R.A., Kader N.A. and Roy, N.K. (2021). Physicochemical study of livestock farm oriented wastewater as a source of surface water pollution. J. Anim. Res., 11(3): 421-431.

Source of Support: None; Conflict of Interest: None 
serious pollution in the particular environment (Chauhan, 2014).

The major proportion of all water quality degradation worldwide is due to anthropogenic causes (Faniran et al., 1994). Human activities interfere in many ways with natural water cycle and affect the society-water relationship. Increasing human population and its expectations regarding the standard of living increase demands on exploitation of existing resources including water (Chowdhury, 2013). The contraceptive-rich pharmaceuticals present in hospital wastewater were reported to be associated with effects of endocrine disruption, for instance, exposure to pharmaceutical waste containing estrogen or androgen caused sex reversals in fishes and thus, reproductive impairment (Obasi et al., 2014).

There is almost a global shortage of water and the world's most urgent and front rank problem today is supply and maintenance of clean drinking water. Water is one of the precious resources on earth and is the basic need of all life forms. Due to rapid urbanization and developments in the animal husbandry sector, many water bodies have been greatly affected. The livestock business is among the most damaging sectors to the earth's increasingly scarce water resources, contributing among other things to water pollution from animal wastes, antibiotics and hormones, chemicals from tanneries, fertilizers and pesticides used to spray feed crops. The elements released from the livestock farmers such as nitrates, chlorides, sulphates when present in small amounts don't have any negative impacts but high level of these elements and prolonged exposure can lead to many health problems by being carcinogens and cumulative poisons. Monitoring of safety of water sources is based on determination of parameters that indicate pollution caused by sewage, animal excrements, storage of waste, animal manure and artificial fertilizers, and other (Sasakova et al., 2013; Fridrich et al., 2014).

Water pollution from livestock farms not only damages the environment but can also kill and sicken animals and human. Since these farms exercise little restraint when it comes to water usage they tend to release wastewater to the water bodies even when neighbouring communities are experiencing water shortage. Worldwide, dairy farms generate large volumes of wastewaters or effluents (DE) which, if discharged directly into watercourses, can have significant environmental impacts (Craggs et al., 2003). Many infectious diseases of animals and humans are waterborne. The agents of these diseases are transferred by ingestion of water contaminated with human or animal feces that contain pathogenic bacteria, viruses and parasites (protozoa, eggs of parasites). They may survive in water for different periods of time depending on many factors. Monitoring of safety of water sources is based on determination of parameters that indicate pollution caused by sewage, animal excrements, storage of waste, animal manure and artificial fertilizers, and other (Sasakova et al. 2013; Fridrich et al., 2014). Excess level of sodium, calcium, magnesium, potassium, chloride, sulphate, bicarbonate, carbonate and nitrate increase the salinity of waterways, leading to changes in aquatic ecosystems. Human anthropogenic activities are the main causative agents in the increase of nutrients like phosphate, chloride and calcium and ultimately lead to eutrophication (Shekhar et al., 2008).

Different developing countries including India lack proper waste treatment and their disposal. This has led to the release of waste and waste water from livestock farms directly to the nearby land and water bodies thus playing a crucial role in creating surface and ground water pollution. Though many countries have developed different techniques and strategies to mitigate the problem but it is in infant stage in India, particularly for the huge amount of wastewater produced from livestock farms. India has been facing newer and abundant threats due to the rapidly increasing pollution of surface water bodies. This is mostly due to the lack of knowledge and scientific procedures to dispose off wastes. Although surface water pollution studies have received tremendous momentum in recent times, unfortunately it is in infant stage in Assam. Quality monitoring of waste water released from farms has generally been overlooked for various reasons.

A perusal of literature revealed that systematic investigation for monitoring the quality of wastewater from different farms has not been well documented. The present work has been undertaken with a view to evaluate the physicochemical status of wastewater that are liberated from different farms to cause surface water pollution and to strengthen the data base on farm oriented wastewater. 


\section{MATERIALS AND METHODS}

\section{Sampling Station}

Intensive Cattle Development Project (ICDP), Khanapara, Guwahati: The wastewater discharged from the farm at ICDP is carried out from the farm by a drain. The samples were collected from surface water body receiving the wastewater.

Instructional Cattle Farm, College of Veterinary Science, Assam Agricultural University, Khanapara Campus. It houses a dairy farm and a bull shed. The samples were collected from surface water body receiving the wastewater.

Private farm I: It is a dairy farm located at Khanapara. The samples were collected from surface water body receiving the wastewater.

Private farm II: It is a dairy farm located at Khanapara. The samples were collected from surface water body receiving the wastewater.

Private farm III: It is a dairy farm located at Khanapara. The samples were collected from surface water body receiving the wastewater.

\section{Sampling Sources:}

A total of 5 different sampling sources as described earlier were used for collection. Of these 5 sources, 2 were Government farms and 3 were organized private farms.

Table 1: Distribution of sampling sources of wastewater

\begin{tabular}{lllll}
\hline $\begin{array}{l}\text { SI. } \\
\text { No. }\end{array}$ & Station & Location & Source type & $\begin{array}{l}\text { Source } \\
\text { number }\end{array}$ \\
\hline 1 & $\begin{array}{l}\text { Intensive Cattle } \\
\text { Development } \\
\text { Project(ICDP) }\end{array}$ & Khanapara & $\begin{array}{l}\text { Surface } \\
\text { Waterbody }\end{array}$ & S1 \\
2 & $\begin{array}{l}\text { Instructional Cattle } \\
\text { Farm }\end{array}$ & Khanapara & $\begin{array}{l}\text { Surface } \\
\text { Waterbody }\end{array}$ & S2 \\
3 & Private farm I & Khanapara & $\begin{array}{l}\text { Surface } \\
\text { Waterbody }\end{array}$ & S3 \\
4 & Private farm II & Khanapara & $\begin{array}{l}\text { Surface } \\
\text { Waterbody }\end{array}$ & S4 \\
& Private farm III & Khanapara & $\begin{array}{l}\text { Surface } \\
\text { Waterbody }\end{array}$ & S5 \\
\hline
\end{tabular}

Journal of Animal Research: v. 11, n. 3, June 2021

\section{Collection of Sample}

The samples were collected, stored and preserved as per methods described by American Public Health Association (APHA, 1998).

The water samples were collected once a month in precleaned polyethylene (plastic) containers of $2500 \mathrm{ml}$ capacity covering all the seasons starting from March 2011 to September 2011. The containers were pre-cleaned and rinsed with distilled water several times and dried thoroughly before use. Water samples were collected in sterilized glass bottles for bacteriological analysis. The containers were filled and stoppered tightly to avoid air contact and agitation during transport. The samples were collected from different locations in and around the point of discharge and natural water bodies receiving the waste water.

\section{Storage and preservation of samples}

Standard procedure (APHA, 1998) was followed for storage and preservation of samples. The parameters, viz, temperature, turbidity, electrical conductivity, $\mathrm{pH}$, Dissolved Oxygen were measured at the time of collection of the samples.

\section{Chemicals and reagents}

In the present study all chemicals used were from E. Marck and were of analytical grade. The solutions used in the study were made in double distilled deionised water. In the study Borosil glassware and Tarson plastic wares were used. The equipment's were calibrated carefully using standard methods as described by APHA (1998). Adequate precautions were taken to avoid possible contamination of containers, beakers, flasks etc. Stock standard solutions were prepared by dissolving ultrapure metals/compounds (99 99\% pure).

\section{Management of farm wastewater}

The farm wastewater management systems in different farms were studied by preparing questionnaires.

\section{Physicochemical properties}

\section{Determination of temperature}

The temperature was determined as per methods described 
by Swarup et al. (1992). The wastewater samples were taken in plastic containers and a mercury thermometer was dipped into these samples for nearly one minute to record the temperature. A mercury thermometer of $0^{\circ}$ to $50^{\circ} \mathrm{C}$ range was used in the present study.

\section{Determination of Total Alkalinity}

The total alkalinity of wastewater samples was determined as per the method described by Swarup et al. (1992). The total alkalinity was measured by titration of the water sample with a standard sulphuric acid solution. The water sample $(50 \mathrm{ml})$ was taken in a conical flask and 2-3 drops of phenolphthalein indicator were added to the flask. Development of no pink colour in the flask indicated absence of phenolphthalein alkalinity. Then 2-3 drops of methyl orange indicator was added to the flask and the water sample was titrated by N/50 sulphuric acid till the orange colour changed to pink. The total alkalinity of the wastewater samples was expressed in $\mathrm{mg} / \mathrm{l}$.

\section{Determination of Sulphate}

The sulphate concentration was determined by turbidimetric method (Swarup et al., 1992). Using digital spectrophotometer (UV-VIS Spectrophotometer 117 , Systronics). The sample $(5 \mathrm{ml})$ was taken in a 25 $\mathrm{ml}$ round bottom flask and $10 \mathrm{ml}$ sodium acetate acetic acid buffer and $1 \mathrm{ml}$ of $0.25 \%$ gum acacia were added. After a few minutes $1 \mathrm{gm}$ of barium chloride was added, the flask was then shaken gently for few minutes till all the barium chloride was dissolved and the volume was made upto $25 \mathrm{ml}$. A calibration curve was obtained by measuring turbidities of standard sodium sulphate solution. Absorbance reading was taken with the help of spectrophotometer at $440 \mathrm{~nm}$. Sulphate concentration was expressed in $\mathrm{mg} / 1$.

\section{Determination of Total Dissolved Solids (TDS)}

Determination of total dissolved solids was done as per the methods described by APHA (1998). Total dissolved solids were determined as the filtrate left after evaporation of a measured volume of the filtered sample. The sample was filtered through a filter paper (Whatman No 4) and was evaporated to dryness in a pre-weighted borosil beaker in a water bath. The filtrate and the beaker were further dried in an oven at $103-105^{\circ} \mathrm{C}$ till a constant weight was obtained. The total dissolved solid was expressed in $\mathrm{mg} / \mathrm{l}$.

\section{Determination of Total Suspended Solids (TSS)}

Determination of total suspended solids was done as per the methods described by APHA (1998). The residue left on the filter paper after filtration of the sample was dried till a constant weight was obtained. The total suspended solids was expressed in $\mathrm{mg} / \mathrm{I}$.

\section{Determination of Total Solids (TS)}

Determination of total solids was done as per the methods described by APHA (1998). The sample was taken on a beaker without filtration and dried till a constant weight was obtained. The total solids was expressed in $\mathrm{mg} / \mathrm{I}$.

\section{Determination of Chloride}

Chloride contents of the wastewater samples were determined by argentometric method as described by APHA, (1998). The wastewater sample was titrated against silver nitrate $\left(\mathrm{AgNO}_{3}\right)$ solution using potassium chromate $(\mathrm{KCrO})$ as an indicator; chloride ions were quantitatively precipitated first as silver chloride $(\mathrm{AgCl})$; after elimination of all chloride ions, silver chromate $\left(\mathrm{AgCrO}_{4}\right)$ gets precipitated giving a permanent reddish tingle appearance which indicates the end point. Chloride concentration was expressed in $\mathrm{mg} / \mathrm{I}$.

\section{Determination of Calcium}

Calcium was determined by EDTA titrimetric method (APHA, 1998). The sample $(50 \mathrm{ml})$ was taken in a conical flask and $1 \mathrm{ml}$ of Sodium hydroxide (8\%) and a Pinch of murexide indicator were added. The solution was then titrated against EDTA solution until the pink colour changes to purple. Calcium concentration was expressed in $\mathrm{mg} / \mathrm{l}$.

\section{Determination of Nitrate}

Nitrate contents of the wastewater samples were determined by Phenol-disulphonic acid method as described by APHA (1998) using digital spectrophotometer (UV-VIS Spectrophotometer 117, Systronics). The sample (25 ml) 
was taken in a borosil beaker and evaporated to dryness in a hot water bath. To the residue $0.5 \mathrm{ml}$ of phenol disulphonic acid was added to dissolve the residue. Then $5 \mathrm{ml}$ of distilled water and $1.5 \mathrm{ml}$ of potassium hydroxide $(12 \mathrm{~N})$ solution were added and mixed thoroughly by stirring. The nitrate content was read directly by operating the instrument in photometry mode calibrating against a standard and a blank at $410 \mathrm{am}$.

\section{Determination of Turbidity}

Turbidity of the wastewater samples was determined by using Deluxe Water and Soil Analysis Kit (Model, No. 191E). The turbidity sampler was connected to the instrument sampler socket and was then allowed to warm up for 2 minutes after switching on the turbidity function. Distilled water was taken in a test tube and was then inserted in the turbidity sampler. After that the lid was closed. The display was adjusted to 000 by adjusting the Zero set knob. The test tube containing distilled water was removed and another test tube containing standard solution (200 NTU) was placed in the turbidity sampler. The measurement of the buffer suspension was taken and the knob was calibrated to read 200 NTU. The display zero was again checked with the test tube containing distilled water. Then the sample was put in the test tube and inserted in the turbidity sampler to determine the turbidity in terms of NTU.

\section{Determination of $\mathrm{pH}$}

$\mathrm{pH}$ of the wastewater samples was determined by Water and Soil Analysis Kit (Model, No 191E). The function switch was put to $\mathrm{pH}$ mode and the electrode was rinsed with distilled water and dried with a tissue paper. The electrode BNC plug was connected at the input socket. Then the combination $\mathrm{pH}$ electrode was put in $7.00 \mathrm{pH}$ buffer solution and the temperature compensation knob was set to the temperature of the buffer solution. After that the display value was read and adjusted with CAL control to $7.00 \mathrm{pH}$. The electrode was then taken out from $7.00 \mathrm{pH}$ buffer and rinsed with distilled water and dried with a tissue paper. The electrode was then put in $4.00 \mathrm{pH}$ buffer solution and the display value was set to $4.00 \mathrm{pH}$. After that the electrode was taken out from $4.00 \mathrm{pH}$ buffer and rinsed with distilled water and dried. The process was repeated once more. Then the $\mathrm{pH}$ electrode was put in the wastewater samples to determine the $\mathrm{pH}$.

\section{Determination of Electrical Conductivity}

The electrical conductivity of the wastewater samples was determined by Water and Soil Analysis Kit (Model, No. 191E). The conductivity cell was cleaned with distilled water, dried and connected at COND input. After that the function switch was put at COND position. The Cond. Cell was dipped in solution under test and the electrical conductivity was measured.

\section{Determination of Dissolved Oxygen}

Dissolved Oxygen of the wastewater samples was determined by DO METER (MODEL No. 314). The DO probe was prepared as per the instruments guideline. The instrument was switched on and the prepared DO probe was attached to the PROBE connector. The probe was allowed to polarize for 15 minutes. After calibration, the PROBE was placed in the sample to be measured. The samples were continuously stirred during the measurement to prevent depletion of DO near the membrane of the PROBE. Then the digitally displayed result of dissolved oxygen in terms of $\mathrm{mg} / \mathrm{l}$ was recorded.

\section{Determination of Biochemical Oxygen Demand (BOD)}

The Biochemical Oxygen Demand of the wastewater samples was determined by 5 days incubation at $20^{\circ} \mathrm{C}$, The initial Dissolved Oxygen Concentration was measured before incubation and after 5 days incubation the final Dissolved Oxygen Concentration was measured to determine the Biochemical Oxygen Demand of the wastewater samples, BOD was expressed in $\mathrm{mg} / \mathrm{l}$.

Statistical analysis of the recorded data has been done by 2 way ANOVA as per standard methods described by Snedecor and Cochran (1994).

\section{RESULTS AND DISCUSSION}

The data on physicochemical quality of livestock farm oriented waste water from five different sources in different animal farms in and around Khanapara were recorded for a period of seven months (from March 2011 to September 2011) on a monthly basis.

\section{Determination of Farm waste water management}

In the present study it has been recorded that $100 \%$ of the 
livestock farms directly discharge their wastewater into the nearby water body, don't adopt any measure to clean the water body where the wastewater is discharged, use disinfectants to clean the farm premises and discharge the medicinal residues into the water bodies. None $(0 \%)$ of them have any wastewater treatment plant and a daily routine to clean the water body. $60 \%$ of the livestock farms have tube wells, wells etc.

\begin{tabular}{lll}
\hline \multicolumn{1}{c}{ Questions } & Response \\
\hline 1 Do you have any wastewater treatment plant? & $0 \%$ \\
2 & $\begin{array}{l}\text { Do you directly discharge the wastewater into the } \\
\text { nearby water body? }\end{array}$ & $100 \%$ \\
3 & Do you adopt any measure to clean the water body & $100 \%$ \\
where the wastewater is discharged? & \\
4 & $\begin{array}{l}\text { Do you maintain a daily routine to clean the water } \\
\text { body? }\end{array}$ & $0 \%$ \\
5 & $\begin{array}{l}\text { Do you use disinfectants to clean the farm } \\
\text { premises? }\end{array}$ \\
6 Do you discharge the medicinal residues into the & $100 \%$ \\
& $\begin{array}{l}\text { water bodies? } \\
7\end{array}$ & $\begin{array}{l}\text { Is there any well, tube well etc from where human } \\
\text { beings get their water supply? }\end{array}$ \\
\hline
\end{tabular}

\section{Determination of physicochemical properties}

\section{Determination of temperature}

Temperature is one of the most important ecological factors, which controls the physiological behaviour and distribution and influence the aquatic ecology (Huet.,1986). The mean temperature $\left({ }^{\circ} \mathrm{C}\right)$ of wastewater samples recorded were $24.45 \pm 0.02,27.87 \pm 0.03,25.51$ $\pm 0.02,23.41 \pm 0,02,20.96 \pm 0.05,18.21 \pm 0.02$ and $20.82 \pm 0.05$ in March, April, May, June, July, August and September respectively. In the present highly significant variation $(\mathrm{P}<0.05)$ was observed between the different months. The highest mean temperature $(27.87 \pm 0.03)$ was recorded in the month of April due to very low water table, clear atmosphere and high solar radiation in comparison to the other months and the lowest mean temperature $(18.21 \pm 0.02)$ was recorded in the month of August due to very high water table and runoff in Comparison to the other months which leads to low water temperature. It has been observed that from the month of May till August the temperature of water decreased, It may be attributed due to the rainfall which led to the increase in the water table and runoff, thus decreasing the water temperature In the month of September, the water temperature was seen to increase which can be attributed to the absence of rainfall $17 \mathrm{f}$ the particular month Similar findings were observed by Izonfuo and Bariwens (2001) while studying the effect of urban runoff water on physicochemical parameters of pyre Creek in Niger Delta.

\section{Determination of total alkalinity}

Alkalinity is a measure of the ability of water to neutralize acids. It plays an important role in controlling the enzyme activities in water. The mean alkalinity $(\mathrm{mg} / \mathrm{l})$ of wastewater samples in March, April, May, June, July, August and September were 49.23 $\pm 0.23,50.25 \pm 0.03$, $48.50 \pm 0.14,47.15 \pm 0.04,46.49 \pm 0.05,45.00 \pm 0.05$ and $46.33 \pm 0.04$ respectively. In the present study, highly significant variation $(\mathrm{P}<005)$ was observed between the different months. The minimum $(45.00 \pm 0.05)$ total alkalinity measured was observed in the month of August and maximum $(50.25 \pm 0.03)$ was observed in the month of April. High level of alkalinity can be attenuated to the low water level, which leads to concentration of the alkaline substances and low level of alkalinity can be attributed to the high water content, thus leading to dilution of the alkaline substances It has been observed in the Present study that from the month of May to August the alkalinity level decreased. Thus may occur due to the dilution of the alkaline substances by rainfall. Similar trend was observed by Ibrahim et al. (2009) while assessing the physico-chemical parameters of Kontagora reservoir. They recorded higher $(53.38 \mathrm{mg} / \mathrm{l})$ dry season mean alkalinity and lower $(34.99 \mathrm{mg} / 1)$ wet season mean alkalinity According to Venkateswarlu (1969) alkalinity concentration is affected directly by rainfall.

\section{Determination of Sulphate}

According to De (1989) excessive sulphate content of drinking water may cause cathartic effect. The mean sulphate concentration $(\mathrm{mg} / \mathrm{l})$ of wastewater samples in March, April, May, June, July, August and September were $162.92 \pm 0.73,165.65 \pm 0.62,158.72 \pm 0.93,154.98$ $\pm 0.51,151.76 \pm 0.64,145.99 \pm 0.47$ and $150.98 \pm 0.54$ respectively. In the present study, highly significant variation $(\mathrm{P}<0$ 05) was observed between the different months. The lowest mean sulphate concentration (145.99 
$\pm 0.47)$ was recorded in the month of August and highest $(165.65 \pm 0.62)$ in the month of April. The lowest mean sulphate concentration in the month of August can be attributed to the highest water level in the water bodies as compared to other months under study which leads to dilution of the sulphate content. The highest mean sulphate concentration in the month of April can be attributed to the lowest water level due to high environmental temperature and high rate of evaporation which leads to concentration of this parameter. In the present study it has been observed that from the month of May to August, the mean sulphate concentration decreased. This can occur due to dilution effect caused by rainfall, The increase sulphate concentration in the month of September may be due to the lack of rainfall in comparison to the previous four months, Sharma and Dubey (2011), during their assessment of municipal wastewater of Indore city observed that sulphate concentration in the monsoon season was low as compared to the sulphate concentration in the premonsoon season.

\section{Determination of Total Dissolved Solids (TDS)}

Dissolved solids may either be organic or inorganic. Water with high total dissolved solids is of inferior palatability and can induce an unfavourable physiochemical reaction in the consumers. The mean Total Dissolved Solids concentration $(\mathrm{mg} / \mathrm{l})$ of wastewater samples in March, April, May, June, July, August and September were $860.11 \pm 1.00,860.71 \pm 1.22,857.61 \pm 2.01,855.39 \pm$ $2.00,850.04 \pm 1.99,845.41 \pm 1.05$ and $851.22 \pm 1.23$ respectively. In the present study, Significant variation $(\mathrm{P}<0.05)$ was observed between the different months. The lowest mean concentration $(845.41 \pm 1.05)$ of Total Dissolved Solids was recorded in the month of August and the highest mean concentration $(860.71 \pm 1.22)$ of Total Dissolved Solids was recorded in the month of April. The lowest mean concentration of Total dissolved solids in the month of August can occur due to dilution of the dissolved solids by the high water content and the highest mean concentration of Total Dissolved Solids in the month of April can be attributed to the concentration effect caused by low water level and high rate of evaporation. In the present study it has been observed that from the month of May till August, the Total Dissolved Solids concentration decreased. This can be attributed to the dilution effect caused by rainfall. In the month of September the Total
Dissolved Solids concentration increased because of absence of rainfall. Maitera et al. (2011) while evaluating the physical parameters of river Gongola in Nigeria found that the mean concentration of Total Dissolved Solids in dry season was high (123.00 to $139.00 \mathrm{mg} / \mathrm{l})$ and that for wet season was low (105.45 to $116.83 \mathrm{mg} / \mathrm{l})$. The low value of Total Dissolved Solids in rainy season may be due to the dilution of water caused by rain water and runoff (Izonfuo and Bariweni, 2001).

\section{Determination of Total Suspended Solids (TSS)}

Suspended solids cause ecological imbalance in the aquatic ecosystem by mechanical abrasive action. As levels of Total Suspended Solids increase, a water body begins to lose its ability to support a diversity of aquatic life. The mean Total Suspended Solids concentration $(\mathrm{mg} / \mathrm{l})$ of wastewater samples in March, April, May, June, July, August and September were $843.43 \pm 1.00$, $840.24 \pm 1.63,852.80 \pm 1.50,856.07 \pm 0.98,868.22 \pm$ $0.97,875.40 \pm 1.02$ and $869.20 \pm 1.44$ respectively. In the present study, highly significant variation $(\mathrm{P}<0.05)$ was observed between the different months. The highest recorded value $(875.40 \pm 1.02)$ of total suspended solids was observed in the month of August because of increased runoff and was lowest $(840.24 \pm 1.63)$ in the month of April because of absence of runoff as there was no rainfall in that month. It has been observed that from the month of May till August, the total suspended solids concentration increased. This may be attributed to the rainfall which led to the runoff thus adding to the suspended solids concentration. Agarwal and Rajwar (2010) during their physicochemical and microbiological study of Tehri dam reservoir found similar trend in the Total Suspended Solids concentration. They recorded the highest mean $(116 \mathrm{mg} / \mathrm{l})$ Total Suspended Solids in rainy season and the lowest mean $(13.8 \mathrm{mg} / \mathrm{l})$ Total Suspended Solids in dry season. They suggested that the higher values of Total Suspended Solids in rainy season can occur due to increased surface run-off.

\section{Determination of Total Solids}

The mean Total Solids concentration (mg/l) of wastewater samples in March, April, May, June, July, August and September were $1703.53 \pm 1.03,1700.96 \pm 1.00,1710.41$ $\pm 1.10,1711.47 \pm 0.99,1718.26 \pm 0.98,1720.81 \pm 1.00$ 
and $1720.42 \pm 0.97$ respectively. In the present study highly significant variation $(\mathrm{P}<0.05)$ was observed between the different months. The highest mean Total Solids concentration $(1720.81 \pm 1.00)$ was recorded in the month of August and the lowest $(1700.96 \pm 1.00)$ Total Solids concentration was recorded in the month of April. The highest mean Total Solids concentration recorded in the month of August was due to high surface runoff thus adding to the Total Solids concentration and the lowest mean total Solids concentration recorded in the month of April was due to absence of runoff. This may be also attributable to the high Total Suspended Solids concentration in the month of August that was observed in the present study.

\section{Determination of Chloride}

The presence of Chloride in natural water can be attributed to the salt deposits, discharge of effluents, sewage discharges etc. In natural surface water the concentration of Chloride is generally low. The mean Chloride concentration (mg/l) of wastewater samples in March, April, May, June, July, August and September were $162.41 \pm 0.03,164.53 \pm 0.03$, $162.44 \pm 0.03,158.40 \pm 0.01,152.48 \pm 0.05,148.19 \pm 0.02$ and $151.79 \pm 0.01$ respectively. In the present study, highly significant variation $(\mathrm{P}<0.05)$ was observed between the different months. The lowest $(148.19 \pm 0.02)$ mean chloride concentration $(\mathrm{mg} / \mathrm{l})$ was recorded in the month of August and highest $(164.53 \pm 0.03)$ in the month of April. In the month of August the mean chloride concentration was lowest because of the highest level of dilution of the parameter caused by high water level but in the month of April, concentration of chloride was maximum because of very low water level due to absence of rainfall. Sisodia and Moundiotiya (2006) while studying the water quality of Kalaho Lake recorded lowest Chloride level in the rainy season and highest in the ay season.

\section{Determination of Calcium}

Calcium is one of the most abundant substances in natural water. Disposal of wastes to water bodies also leads to an increase Calcium content. Calcium is essential for all living organisms as it regulates various physiological functions. The mean Calcium concentration $(\mathrm{mg} / \mathrm{l})$ of wastewater samples in March, April, May, June, July, August and September were 170.13 $\pm 0.03,175.81 \pm$
$0.03,174.24 \pm 0.03,172.99 \pm 0.05,158.47 \pm 0.03,155.99$ \pm 0.05 and $161.26 \pm 0.03$ respectively. In the present study, highly significant variation $(\mathrm{P}<0.05)$ was observed between the different months. The lowest $(155.99 \pm 0.05)$ mean concentration of calcium $(\mathrm{mg} / \mathrm{l})$ was recorded in the month of August due to heavy dilution of the parameter and highest $(175.81 \pm 0.03)$ in the month of April due to concentration effect. It has been observed in the present study that the mean calcium concentration decreased from the month of May till August. This may be attributed to the rainfall leading to decrease concentration of the parameter. However, the increased concentration of calcium in the month of September may be due to the absence of rainfall. Izonfuo and Bariweni (2001) while studying the effect of urban runoff water and human activities in the Niger Delta also recorded lower $(4.25 \mathrm{mg} / \mathrm{l})$ calcium concentration in the rainy season than in the dry season $(6.51 \mathrm{mg} / \mathrm{l})$. The runoff water contributes to dilution of the parameter in the rainy season which lowers the concentration of calcium in the water bodies,

\section{Determination of Nitrate}

Nitrate is not harmful as such, but when converted to nitrite in the body inhibits the oxygen carrying capacity of haemoglobin, The most important source of nitrates is biological oxidation of nitrogenous substances present in sewage, agricultural wastes, chemical fertilizers, decayed vegetables, animal feed lots, leachates from refuse dumps, septic tank effluent, etc. The mean Nitrate concentration $(\mathrm{mg} / \mathrm{l})$ of wastewater samples in March, April, May. June, July, August and September were 245.98 \pm 0.03 , $248.98 \pm 0.04,242.78 \pm 0.01,235.80 \pm 0.02,229.26 \pm$ $0.02,221.06 \pm 0.00$ and $233.46 \pm 0.04$ respectively. In the present study, highly significant variation was observed between the different months, The lowest (221.06 \pm $0.00)$ mean concentration of nitrate was recorded in the month of August because of the heavy dilution caused by high rate of rainfall and the highest $248.98 \pm 0.04$ ) mean concentration was recorded in the month of April because of high concentration effect caused by low water level due to absence of rainfall. In the present study it has been observed that the mean nitrate concentration decreased frond the month of May till August. It may be attributed to the dilution of Nitrate content caused by rainfall and runoff, Sharma et al. (2008) while studying the limnology and microbiology of Udaipur lakes recorded the lowest 
mean concentration of nitrate $(1.17-1.32 \mathrm{mg} / \mathrm{l})$ in the rainy season and the highest $(1.55-2.02 \mathrm{mg} / \mathrm{l})$ in the dry season.

\section{Determination of Turbidity}

Clay, silt, organic matter, plankton and other microscopic organisms cause turbidity in water recognized as a valuable limiting factor in the biological productivity of water bodies (Kishore et al., 2005). The contributing factors of high turbidity level particularly in the rainy season are soil erosion, high flow rate, decayed vegetation etc. (APHA, 1998). The mean Turbidity (NTU) of wastewater samples in March, April, May, Jone, July, August and September were $936.80 \pm 0.98,936.00 \pm 1.04,937.64 \pm 1.03,938.20$ $\pm 1.03,941.32 \pm 0.87,943.52 \pm 1.04$ and $941.02 \pm 1.03$ respectively. In the present study, highly significant variation $(\mathrm{P}<0.05)$ was observed between the different months. The highest $(943.52 \pm 1.04)$ mean concentration of turbidity was recorded in the month of August and the lowest $(936.00 \pm 1.04)$ mean concentration was recorded in the month of April. This can be attributed to the highest surface runoff in August and absence of runoff in the month of April. In the present study it has been observed gat the mean turbidity concentration increased from the month of May till August. This may be attributed to the rainfall and runoff thus increasing the turbidity concentration. Similar trend of turbidity concentration was observed by Sa'id and Jimoh (2009) while measuring some physical parameters in water samples in Kano Metropolis in Nigeria, They recorded turbidity level upto 25 NTU in the dry season and upto 39 NTU in the rainy season, The high turbidity levels recorded in the rainy season may occur due to addition of sand, silt etc. to the sampling points by rainwater. Garget al. (2010) while studying the seasonal variations in water quality in Ramsagar Reservoir also observed similar findings.

\section{Determination of $\mathrm{pH}$}

Measurements of $\mathrm{pH}$ provide a quick and easy to obtain appraisal of the acid base equilibrium in an ecological system. WHO and ICMR have recommended maximum permissible limits of $\mathrm{pH}$ to be 6.58 .5 and 6.592 respectively. The mean $\mathrm{pH}$ of wastewater samples in March, April, May, June, July, August and September were $11.10 \pm 0.12,12.20$ $\pm 0.23,10.33 \pm 0.34,9.73 \pm 0.10,8.41 \pm 0.03,7.60 \pm 0.04$ and $8.18 \pm 0.04$ respectively. In the present study, highly significant variation $(\mathrm{P}<0.05)$ was observed between the different months. The highest $(12.20 \pm 0.23)$ mean $\mathrm{pH}$ was recorded in the month of April because of highest concentration of alkaline substances in the month and the lowest $(7.60 \pm 0.04)$ mean $\mathrm{pH}$ was recorded in the month of August because of dilution of the alkaline substances to a very low level by rainfall during the period. in the present study it has been observed that the mean $\mathrm{pH}$ level decreased from the month of May till August, This may be attributed to the dilution effect caused by rainfall, Sisodia and Moundiotiya (2006) recorded high $\mathrm{pH}$ level of 7.9 to 8.37 during dry season and low $\mathrm{pH}$ level of 7.05 to 7.27 during monsoon season. High $\mathrm{pH}$ can be attributed to high temperatures, which enhance microbial activity causing excessive production of $\mathrm{CO}_{2}$.

\section{Determination of electrical conductivity}

Electrical conductivity is a measure of the capacity of a substance or solution to conduct electric current, This parameter is a general indicator of water quality, especially a function of the amount of dissolved salt. The mean Electrical Conductivity $(\mathrm{ms} / \mathrm{cm})$ of wastewater samples in March, April, May, June, July, August and September were $16.24 \pm 1.00,18.00 \pm 1.12,15.21 \pm 2.00,14.04 \pm 1.03$, $13.13 \pm 1.14,10.20 \pm 1.02$ and $11.64 \pm 1.01$ respectively. In the present, highly significant variation $(\mathrm{P}<0.05)$ was observed between the different months, The highest (18.00 \pm 1.12 ) mean electrical conductivity was recorded in the month of April because of highest concentration of the ions as a result of reduced water volume and the lowest (10.20 \pm 1.02 ) mean electrical conductivity was recorded in the month of August because of lowest concentration of lone, it has been observed goat the mean electrical conductivity decreased from the month of May till August. It may be attributed to the rainfall which leads to dilution of the ions resulting in decrease electrical conductance, similar trend of electrical conductivity values were recorded by Ibrahim et al. (2009) during their assessment of physicochemical parameters of Kontagora reservoir. They recorded the highest electrical conductivity value in the dry season and the lowest in the rainy season,

\section{Determination of dissolved oxygen}

Dissolved Oxygen is a measure of the degree pollution by organic matter, the destruction of organic substances 
as well as the self-purification capacity of the water body. The mean Dissolved Oxygen concentration (mg/l) of wastewater samples in March, April, May, June, July, August and September were $15.41 \pm 1.44,14.30 \pm 1.30$, $16.23 \pm 1.03,16.50 \pm 1.16,17.00 \pm 1.14,18.39 \pm 1.10$ and $17.59 \pm 1.15$ respectively. In the present study, highly significant variation $(\mathrm{P}<0.05)$ was observed between the different months. The highest $(18.39 \pm 1.10)$ mean concentration of dissolved oxygen was recorded in the month of August and the lowest $(14.30 \pm 1.30)$ mean concentration of dissolved oxygen was recorded in the month of April. The maximum concentration of dissolved oxygen is due to heavy rainfall which favors solubility of oxygen and the minimum concentration is due to absence of rainfall leading to decrease solubility of oxygen. In the present study, it has been observed that the dissolved oxygen concentration increases from May to August It may be due to the rainfall thus leading to creased solubility of oxygen in the water. Nair et al. (2006) while studying the ground water quality of north east Libya gated that addition of rain water rich in oxygen can increase the level of oxygen in water. Koli and Ranga (2011) have stated that high temperature decreases oxygen holding capacity of water Adedokun (2008) during their study on the river system in Ibadan Metropolis also recorded higher (upto31mg/l) dissolved oxygen during the any season and lower (upto $8.2 \mathrm{mg} / \mathrm{l}$ ) during the dry season.

\section{Determination of biochemical oxygen demand}

Biochemical Oxygen Demand is the amount of oxygen required by the living organisms engaged in the utilization and ultimate destruction or stabilization of organic wastes. The mean Biochemical Oxygen Demand (mg/l) of wastewater samples in April, May, June, July, August and September were $16.07 \pm 1.70,18.25 \pm 1.42,15.50 \pm$ $1.56,12.79 \pm 1.12,10.87 \pm 1.42,8.49 \pm 1.02$ and $15.30 \pm$ 1.00 respectively. In the present study, highly significant variation $(\mathrm{P}<0.05)$ was observed between the different months. The highest $(18.25 \pm 1.42)$ mean concentration of Biochemical Oxygen Demand $(\mathrm{mg} / \mathrm{t})$ was recorded in the month of April and the lowest (8.49 \pm 1.02$)$ mean concentration of Biochemical Oxygen Demand was recorded in the month of August. The maximum Biochemical Oxygen Demand in the month of April may be due to maximum bacterial load in that month and the minimum Biochemical Oxygen Demand in the month of August may be due to low bacterial load in the month It has been observed in the present study that the Biochemical Oxygen Demand decreased from the month of May till August. This may be attributed to the decrease in the bacterial load from the month of May till August. Similar trend of values of Biochemical Oxygen Demand were recorded by Izonfuo and Bariweni (2001). They recorded higher Biochemical Oxygen Demand values in the dry season and lower values in the rainy season. The lower Biochemical Oxygen Demand values in the rainy season were due to dilution of water caused by rain and runoff.

\section{CONCLUSION}

Surface water pollution by waste water from livestock farms is one of the main problem in India particularly in the North eastern region. Due to lack of proper knowledge and resources, the surface water bodies are polluted to a great extent which can lead to ecological imbalances and health hazards. From the findings of the present investigation it can be concluded that the waste water samples appeared to have high amount of Total Dissolved Solids, Nitrate, ${ }_{\mathrm{p}} \mathrm{H}$, and Biochemical Oxygen Demand. However, concentrations of sulphate, chloride, calcium, and temperature were found to be low. Proper waste water treatment is required to be done in order to maintain the levels of the parameters that are above the tolerance limits in order to prevent surface water pollution.

\section{REFERENCES}

Adedokun, O.A. 2008. Seasonal Limnological variation and nutrient load of the river system in Ibadan Metropolis, Nigeria. European J. Scl., Res., 23(1): 98-108.

Agarwal, A.K. and Rajwar, G.S. 2010. Physico-chemical and microbiological study of Tehri Dam reservoir, Garhwal Himalaya, India J. Am. Sci., 6(6): 65.

Akter, N., Kazi, N.N. and Chowdhury, A.M.R. 1999. Environmental investigation of medical waste management system in Bangladesh with reference to Dhaka city. DRAC Research and Evaluation Division, Dhaka, pp. 225.

Buelow, E., Bayjanov, J.R., Willems, R.J., Bonten, M.J., Schmitt, H. and Van Schaik, W.2017 The microbiome and resistome of hospital sewage during passage through the community sewer system, bioRxiv 216242.

Chauhan, R.K. 2014. Physicochemical Analysis of Untreated Sewage Water of Ladwa town of Kurukshetra District of 
Haryana and Need of Waste Water Treatment Plant. Int. J. Curr. Microbiol. Appl. Sci., 3(3): 326-333.

Chowdhury, S. 2013. Exposure assessment for trihalomethanes in municipal drinking water and risk reduction strategy. Sci. Total Environ. 463-464, 922-930.

Craggs, R.J., Tanner, C.C., Sukias, J.P.S. and Davis-Colley, R.J. 2003. Dairy farm wastewater treatment by an advance pond system. Water Sci. Tech., 48(2): 291-297.

Fridrich, B., Krcmar, D., Dalmacija, B., Molnar, J., Pesi c, V., Kragulj, M. et al. 2014. Impact of wastewater from pig farm lagoons on the quality of local groundwater. Agric. Water Manag., 135: 40-53.

Faniran, J.A., Adeleke, B.B. and Oderinde, R.A. 1994. Forcados Terminal Integrated Projects Baseline Ecological Studies. Commissioned by Shell Petroleum Development Company of Nigeria.

Garg, R.K., Rao, R.J., Uchchariya, D., Shukla, G. and Saksena, D.N. 2010. Seasonal variations in water quality and major threats to Ramsagar Reservoir, India. African J. Environ. Sci. Technol., 4(2): 61-76.

Huet, M. 1986. Textbook of Fish Culture. $2^{\text {ND }}$ Edn., Fish News Book. Ltd., England.

Ibrahim. B.U., Auta, J. and Balogun, J.K. 2009. An assessment of the physicochemical parameters of Kontagora Reservoir, Niger State, Nigeria. Bayero J. Pure Appl. Sci., 2(1): 64-69.

Izonfuo, L.W.A. and Bariweni, A.P. 2001. The effect of urban runoff water and human activities on some physicochemical parameters of the Epie Creek in the Niger Delta. J. Appl. Sci. Environ. Mgt., 5(1): 47-55.

Koli, V.K. and Ranga, M.M. 2011. Physicochemical Status and Primary Productivity of Ana Sagar Lake, Ajmer (Rajasthan), India. Universal J. Environ. Res. Tech., 1(3): 286-292.

Maitera, O.N., Barminas, J.T. and Shinggu, D.Y. 2011. An evaluation of the physical parameters of river Gongola in Adamawa state, Nigeria. Adv. Appl. Sci. Res., 2(6): 62-69.

Nair, G.A., Bohjuari, J.A., Al-Mariami, M.A., Attia, F.A. and ElToumi, F.F. 2006. Ground water quality of north east Libya. J. Env. Biol., 27(4): 695-700.
Obasi, A.I. Amaeze, N.H. and Osoko, D.D. 2014. Microbiological and toxicological assessment of pharmaceutical wastewater from the Lagos Megacity, Nigeria. Chinese. J. Biol., 2014.

Sa'id, M.D. and Jimoh, W.L.O. 2009. Measurement of some physical parameters in some water samples from Kano metropolis, Kano state, Nigeria. Biosci. Res. Comm., 21(3): 133.

Sasakova, N., Veselitz-Lakticova, K., Hromada, R., Chvojka, D., Kosco, J. and Ondrasovic, M. 2013. Contamination of Individual sources of drinking water located in environmentally polluted central $\mathrm{sp}$ is region (Slovakia). $J$. Microbiol. Biotechnol. Food Sci., 3: 262-265.

Sharma, D. and Dubey, 2011. Assessment and treatment of municipal wastewater of Indore city of India. Archives of Applied Sci. Res., 3(1): 450-461.

Sharma, R., Sharma, M.S., Sharma, V. and Malara, H. 2008. Study of limnology and microbiology of Udaipur Lakes. Proc. of the $12^{\text {th }}$ Lake Conference, pp. 1504-1508.

Shekhar, T.R.S., Kiran, B.R. Puttaiah, E.T., Shivaraj, Y. and Mhadevan, K. 2008. Phytoplankton as index of water quality with reference to industrial pollution, J. Env. Boil., 29: 233335.

Sisodia, R. and Moundiotiya, C. 2006. Assessment of the water quality index of wetland Kalaholake, Rajasthan, India. $J$. Environ. Hydrol., 14: 1.

Snedecor, G.W. and Cochran, W.C. 1994. Statistical methods. Oxford and IBS "Publishing Co., Calcutta.

Swarup, R., Mishra, S.N. and Jauhari, V.P. 1992. Encyclopaedia of Ecology, Environment and pollution control-17. Environmental Air and Water Analysis: Mittal Publications, New Delhi.

Venkateswarlu, V. 1969. An ecological study of the algae of the river Moosi, Hyderabad (India) with special reference to water pollution physicochemical complexes. Hydrobiologial, 33: $117-143$. 
